\title{
KINERJA PENGAWAS PENDIDIKAN AGAMA ISLAM
}

\author{
Achmad Habibullah \\ Peneliti Puslitbang Pendidikan Agama dan Keagamaan \\ Badan Litbang dan Diklat Kementerian Agama Republik Indonesia \\ Jl. MH Thamrin No. 06 Jakarta Pusat \\ achmadhabibullah@yahoo.co.id, HP.081361245957
}

\begin{abstract}
The main task of the Islamic education supervisor is to control the quality of Islamic education in schools. However the Ministry of Religious Affairs has not obtained a complete data of this work. As a result, the objective of this research is to collect all the data from the Islamic supervisor related to teacher guidance, supervising national education standard issues, program execution and evaluation. By using the quantity and description method, this research involves 202 Islamic education supervisors and 591 teachers from 20 regional districts in 10 provinces with random sampling selection. The results of this research indicate that the Islamic education supervisor in his task of mentoring and teaching is adequate, the supervising of national education standards is adequate, program management supervision is adequate, and program execution is adequate. However, the task of evaluating the supervision program is less than adequate.
\end{abstract}

Keyword: work, supervisor, Islamic education

\section{Abstrak}

Tugas utama Pengawas Pendidikan Agama Islam adalah melakukan pengendalian mutu penyelenggaraan Pendidikan Agama Islam di sekolah. Namun sampai saat ini, Kementerian Agama belum mempunyai data yang lengkap mengenai kinerja pengawas tersebut. Untuk itu, penelitian ini bertujuan memetakan kinerja Pengawas Pendidikan Agama Islam berkaitan dengan pelaksanaan tugas pembimbingan profesi guru, pemantauan penerapan standar nasional pendidikan, penyusunan program, pelaksanaan program, dan evaluasi program. Dengan menggunakan metode kuantitatif deskriptif, penelitian ini mencakup sebanyak 202 Pengawas PAI dan 591 Guru PAI dari 20 daerah kabupaten dan kota pada 10 provinsi yang dipilih secara simple random sampling. Hasil penelitian menunjukkan bahwa kinerja pengawas PAI dalam pelaksanaan tugas pembimbingan profesi guru mendapat nilai dengan kategori cukup, kinerja dalam pemantauan penerapan standar nasional pendidikan memperoleh nilai dengan kategori cukup, kinerja dalam penyusunan program pengawasan mendapat nilai cukup, kinerja dalam pelaksanaan program pengawasan memperoleh kategori cukup, dan kinerja evaluasi pelaksanaan program pengawasan dengan nilai kategori kurang.

Kata Kunci: Kinerja, Pengawas, Pendidikan Agama Islam

\section{PENDAHULUAN}

Pengawas Pendidikan Agama Islam (PAI) merupakan tenaga kependidikan yang strategik dan penting untuk mengendalikan mutu penyelenggaraan Pendidikan Agama Islampa- da sekolah, terutama melalui pembimbingan profesi atau supervisi edukatif dan akademik kepada guru Pendidikan Agama Islam (PAI). Pembimbingan profesi atau supervisi edukatif tersebut mencakup pembimbingan mulai guru PAI menyusun silabus, rencana pelaksanaan

Naskah diterima 25 Januari 2013. Revisi pertama, 21 Februari 2013. Revisi kedua, 7 Maret 2013 dan revisi terahir 02 April 2013. 
pembelajaran (RPP), pelaksanaan, sampai pembimbingan evaluasi pembelajaran serta membuat saran tindak lanjut yang perlu dilakukan guru PAI. ${ }^{1}$ Melalui pembimbingan tersebut diharapkan guru PAI dapat melaksanakan pembelajaran secara baik dan benar.

Pelaksanaan tugas pengendalian mutu penyelenggaraan Pendidikan Agama Islam tersebut dihadapkan pada kondisi pengawas PAI itu sendiri di lapangan. Kondisi pengawas PAI berdasarkan data yang dikeluarkan oleh Direktorat Jenderal Pendidikan Islam tahun 2010, diketahui bahwa jumlah pengawas Pendidikan Agama Islam ada sebanyak 5.024 orang, di mana $17,6 \%$ berlatar belakang pendidikan diploma, 70,5\% berpendidikan S1, dan sisanya $12 \%$ berpendidikan S2 atau S3. Sedangkan dilihat dari usianya, terdapat 57,7\% pengawas PAI yang berada pada usia 55 tahun atau kurang, dan sisanya, $42,3 \%$ bearada pada usia 56 tahun atau lebih. Pengawas PAI menurut golongan pangkat kepegawaiannya terdiri dari $71,4 \%$ merupakan pegawai golongan IV, dan $28,6 \%$ berpangkat golongan III. Selain itu, terdapat $29,4 \%$ Pengawas PAI berasal dari non pendidikan, dan $38,2 \%$ pengawas PAI berasal dari non guru (mutasi dari jabatan struktural). ${ }^{2}$ Kondisi tersebut menjadi lebih berat melihat pada kenyataan lainnya, yaitu pada umumnya pengawas PAI kurang mendapatkan pendidikan dan pelatihan (diklat) berkaitan dengan tugas-tugas kepengawasan seperti diklat mengenai pengembangan KTSP, dan sebagainya, sedangkan para guru PAI yang menjadi binaannya acapkali mendapatkan diklat yang berkaitan dengan KTSP dan sebagainya. Artinya, pengetahuan dan wawasan kependidikan guru PAI dapat lebih maju dari pengawas PAI, karena dapat mengikuti perkembangan kebijakan pendidikan dan kemajuan dunia pendidikan melalui diklat-diklat dan kegiatan lain yang diikuti. Selain itu, masalah kesejahteraan dan

${ }^{1}$ Kementerian Agama R.I., Peraturan Menteri Agama R.I. Nomor 2 Tahun 2012 Tentang Pengawas Madrasah dan Pengawas Pendidikan Agama Islam pada Sekolah, Pasal 5

${ }^{2}$ Kementerian Agama R.I., Direktorat Jenderal Pendidikan Islam, Buku Statistik Pendidikan Islam Tahun 2010, h. 97-99 fasilitas kendaraan untuk menunaikan tugas pada pengawas PAI dapat dikatakan masih memprihatinkan. Hasil penelitian yang dilakukan Puslitbang Pendidikan Agama dan Keagamaan tahun 2005berkaitan dengan Pokjawas PAI memperlihatkan bahwa hanya 37\% pengawas PAI yang menggunakan kendaraan dinas berupa motor roda dua, $31 \%$ pengawas PAI menggunakan kendaraan milik sendiri, dan 32\% lagi menggunakan kendaraan umum. ${ }^{3}$ Dengan kondisi Pengawas PAI yang demikian itu memunculkan pertanyaan besar yakni bagaimana kinerja Pengawas PAI.

Penelitian Kinerja Pengawas Pendidikan Agama Islam pada Sekolah ini menjadi penting dan strategis karena sampai saat ini belum ada informasi yang dapat menjelaskan secara tepat dan rinci mengenai kinerja pengawas Pendidikan Agama Islam. Hasil penelitian yang ada lebih memetakan pada aspek kompetensinya. Oleh karena itu, penelitian ini lebih memokuskan pada pemetaan kinerja Pengawas Pendidikan Agama Islam secara rinci sebagaimana tugas dan fungsi yang dilaksanakannya sehari-hari.

Tulisan ini diangkat dari hasil penelitian Kinerja Pengawas Pendidikan Agama Islam pada Sekolah yang dilakukan Puslitbang Pendidikan Agama dan Keagamaan pada tahun 2012.Penulis merupakan koordinator kegiatan penelitian tersebut, yang membuat atau menyusun laporan hasil penelitiannya secara keseluruhan dan membuat ringkasan hasil penelitian untuk seminar.Penulis merupakan salah satu peneliti yang bertugas melakukan kegiatan pengumpulan data lapangan.

\section{Perumusan Masalah}

Berdasarkan latar belakang tersebut, dapat dirumuskan permasalahan penelitian ini yakni sejauhmanakinerja Pengawas Pendidikan Agama Islam yang berkaitan dengan pelaksanaan tugas pembinaan, pembimbingan, dan pengembangan profesi guru PAI, peman-

${ }^{3}$ Puslitbang Pendidikan Agama dan Keagamaan, Kinerja Pokjawa Pendidikan Agama Islam pada Sekolah, Jakarta, Tahun 2005, h. 55 
tauan penerapan standar nasional (Standar Isi, Standar Proses, Standar Penilaian, dan Standar Kompetensi Lulusan), penyusunan program pengawasan, pelaksanaan program pengawasan, dan evaluasi pelaksanaan program pengawasan.

\section{Tujuan Penelitian}

Dengan demikian penelitian ini bertujuan memetakan kinerja Pengawas Pendidikan Agama Islam,yang berkaitan dengan:

1. Pelaksanaan tugas pembimbingan profesi guru

2. Pelaksanaan pemantauan penerapan standar nasional

3. Pelaksanaan tugas penyusunan program pengawasan

4. Pelaksanaan tugas pelaksanaan program pengawasan

5. Pelaksanaan tugas evaluasi program pengawasan

\section{Ruang Lingkup Penelitian}

Berdasarkan tujuan penelitian yang ingin dicapai penelitian ini, terdapat lima aspek yang menjadi fokus penelitian ini. Aspek pertama kinerja pengawas Pendidikan Agama Islam (PAI) dalam pelaksanaan tugas pembinaan profesi guru Pendidikan Agama Islam (supervisi akademik), yang kemudian dijabarkan menjadi 10 sub aspek. Kedua, kinerja pengawas PAI dalam melaksanakan tugas pemantauan pelaksanaan standar nasional pendidikan yang terdiri dari standar isi, standar proses, standar penilaian. Ketiga, kinerja pengawas PAI dalam melaksanakan tugas penyusunan program pengawasan, yang terdiri dari 12 sub aspek. Aspek keempat, kinerja pengawas PAI dalam melaksanakan tugas pelaksanaan program pengawasan, yang dijabarkan menjadi 5 sub aspek. Sedangkan pada aspek kelima, kinerja pengawas PAI dalam pelaksanaan tugas evaluasi pelaksanaan program pengawasan tercakup ke dalam $4 \mathrm{sub}$ aspek. Dengan demikian yang menjadi ruang lingkup penelitian ini sebagaimana tergambar pada tabel berikut.
Tabel 1: Ruang Lingkup Penelitian

\begin{tabular}{|c|c|c|}
\hline No. & ASPEK & SUB ASPEK \\
\hline \multirow[t]{10}{*}{1.} & \multirow{10}{*}{$\begin{array}{l}\text { Kinerja Pengawas PAI } \\
\text { dalam pelaksanaan tugas } \\
\text { pembimbingan profesi guru } \\
\text { PAl (Supervisi Akademik) }\end{array}$} & $\begin{array}{l}\text { Pembimbingan konsep, prinsip, teori dasar, } \\
\text { karakteristik, dan kecenderungan perkem- } \\
\text { bangan mata pelajaran PAI }\end{array}$ \\
\hline & & $\begin{array}{l}\text { Pembimbingan konsep, prinsip, teori dasar, } \\
\text { karakteristik, dan perkembangan proses } \\
\text { pembelajaran PAl }\end{array}$ \\
\hline & & $\begin{array}{l}\text { Pembimbingan dalam menyusun silabus } \\
\text { PAl berlandaskan pada standar isi, standar } \\
\text { kompetensi, kompetensi dasar, dan prinsip- } \\
\text { prinsip pengembangan KTSP }\end{array}$ \\
\hline & & $\begin{array}{l}\text { Pembimbingan dalam memilih dan menggu- } \\
\text { nakan strategi, metode, teknik pembelajaran } \\
\text { yang dapat mengembangkan potensi peserta } \\
\text { didik pada mata pelajaran PAl }\end{array}$ \\
\hline & & $\begin{array}{l}\text { Pembimbingan dalam menyusun rencana } \\
\text { pelaksanaan pembelajaran (RPP) PAl }\end{array}$ \\
\hline & & $\begin{array}{l}\text { Pembimbingan kepada guru dalam melaksa- } \\
\text { nakan kegiatan pembelajaran di kelas atau } \\
\text { laboratorium PAl (jika ada), tempat ibadah }\end{array}$ \\
\hline & & $\begin{array}{l}\text { Pembimbingan dalam penggunaan media } \\
\text { pendidikan dan fasilitas pembelajaran }\end{array}$ \\
\hline & & $\begin{array}{l}\text { Pembimbingan dalam memanfaatkan tekno- } \\
\text { logi informasi dalam pembelajaran PAl }\end{array}$ \\
\hline & & $\begin{array}{l}\text { Pemotivasian profesi dan penilaian kinerja } \\
\text { Guru PAl }\end{array}$ \\
\hline & & $\begin{array}{l}\text { Pembimbingan dalam pelaksanaan penelitian } \\
\text { tindakan kelas (PTK) dan menyusun karya } \\
\text { tulis Ilmiah (KTI) }\end{array}$ \\
\hline \multirow[t]{4}{*}{2.} & \multirow{4}{*}{$\begin{array}{l}\text { Kinerja Pengawas PAI } \\
\text { dalam melaksanakan tugas } \\
\text { pemantauan pelaksanaan } \\
\text { standar nasional pendidikan }\end{array}$} & Standar Isi \\
\hline & & Standar Proses \\
\hline & & Standar Penilaian \\
\hline & & Standar Kompetensi Lulusan \\
\hline \multirow[t]{12}{*}{3.} & \multirow{12}{*}{$\begin{array}{l}\text { Kinerja Pengawas PAI } \\
\text { dalam melaksanakan tugas } \\
\text { penyusunan program } \\
\text { pengawasan }\end{array}$} & Menyusun program pengawasan tahunan \\
\hline & & Identitas program pengawasan tahunan \\
\hline & & Pendahuluan program pengawasan tahunan \\
\hline & & $\begin{array}{l}\text { Identifikasi dan analisis hasil pengawasan } \\
\text { program pengawasan tahunan }\end{array}$ \\
\hline & & Matriks program pengawasan tahunan \\
\hline & & Lampiran program pengawasan tahunan \\
\hline & & Matriks program pembinaan guru PAI \\
\hline & & $\begin{array}{l}\text { Matriks program pemantauan pelaksanaan } \\
\text { empat SNP (standar isi, standar proses, } \\
\text { standar penilaian, standar kompetensi } \\
\text { lulusan) }\end{array}$ \\
\hline & & Matriks program penilaian kinerja guru PAI \\
\hline & & Menyusun program pengawasan semesteran \\
\hline & & $\begin{array}{l}\text { Menyusun rencana pengawasan akademik } \\
\text { (RPA) }\end{array}$ \\
\hline & & Instrumen kegiatan pengawasan \\
\hline \multirow[t]{5}{*}{4.} & \multirow{5}{*}{$\begin{array}{l}\text { Kinerja Pengawas PAI } \\
\text { dalam melaksanakan tugas } \\
\text { pelaksanaan program } \\
\text { pengawasan }\end{array}$} & $\begin{array}{l}\text { Melaksanakan pembimbingan guru PAI pada } \\
\text { sekolah }\end{array}$ \\
\hline & & $\begin{array}{l}\text { Memantau pelaksanaan empat SNP (standar } \\
\text { isi, standar proses, standar penilaian, standar } \\
\text { kompetensi lulusan) }\end{array}$ \\
\hline & & Melaksanakan penilaian kinerja guru PAI \\
\hline & & $\begin{array}{l}\text { Menyusun program pembimbingan dan } \\
\text { pelatihan professional guru PAl di kelompok } \\
\text { kerja guru PAI (KKG PAI) /musyawarah guru } \\
\text { mata pelajaran PAI (MGMPPAI) }\end{array}$ \\
\hline & & $\begin{array}{l}\text { Mengevaluasi hasil pelaksanaan pembim- } \\
\text { bingan dan pelatihan guru PAI di KKG PAl/ } \\
\text { MGMP PAI }\end{array}$ \\
\hline
\end{tabular}




\begin{tabular}{|c|c|c|}
\hline \multirow[t]{4}{*}{5.} & \multirow{4}{*}{$\begin{array}{l}\text { Kinerja Pengawas PAI } \\
\text { dalam melaksanakan tugas } \\
\text { evaluasi pelaksanaan } \\
\text { program pengawasan }\end{array}$} & $\begin{array}{l}\text { Mengevaluasi hasil pelaksanaan program } \\
\text { pembinaan guru PAl }\end{array}$ \\
\hline & & $\begin{array}{l}\text { Mengevaluasi hasil pelaksanaan program } \\
\text { pemantauan empat SNP (standar isi, standar } \\
\text { proses, standar penilaian, standar kompe- } \\
\text { tensi lulusan) }\end{array}$ \\
\hline & & $\begin{array}{l}\text { Mengevaluasi hasil pelaksanaan program } \\
\text { penilaian kinerja guru PAl pada sekolah }\end{array}$ \\
\hline & & Membuat laporan pengawasan tahunan \\
\hline
\end{tabular}

\section{METODE PENELITIAN}

\section{Jenis Penelitian}

Penelitian ini merupakan penelitian kuantitatif deskriptif, yaitu penelitian yang mengambil sampel dari populasi, dengan menggunakan kuesioner atau angket sebagai alat pengumpulan data yang pokok. Penelitian ini menggunakan metode kuantitatif deskriptif, yaitu untuk melakukan pengukuran yang cermat terhadap fenomena tertentu,yang dalam hal ini adalah penilaian kinerja Pengawas Pendidikan Agama Islam pada Sekolah.

\section{Lokasi Penelitian}

Lokasi penelitian mencakup provinsi-provinsi yang memiliki jumlah pengawas Pendidikan Agama Islam di atas 200 orang. Berdasarkan acuan demikian, terpilih 10 (sepuluh) provinsi yaitu Sumatera Utara, Sumatera Barat, Riau, Banten, Jawa Barat, Jawa Tengah, Jawa Timur, Kalimantan Selatan, Nusa Tenggara Barat, dan Sulawesi Selatan. Untuk keperluan analisis yang lebih mendalam, dari setiap provinsi tersebut dipilih satu kota dan satu kabupaten, dengan ketentuan bahwa kota dan kabupaten yang dipilih adalah kota dan kabupaten yang memiliki Pengawas PAI lebih dari 10 orang. Kota dan Kabupaten diambil untuk melihat apakah ada perbedaan signifikan kinerja Pengawas PAI. Untuk Sumatera Utara terpilih Kota Medan dan Kabupaten Langkat, Sumatera Barat adalah Kota Padang dan Kabupaten Agam, Riau terdiri dari Kota Pekanbaru dan kabupaten Kampar, Banten diambil Kota Serang dan Kabupaten Tangerang, Jawa Barat terpilih Kota Bandung dan Kabupaten Bogor, Jawa Tengah dipilih Kota Semarang dan Kabupaten Klaten, Jawa Timur terdiri dari Kota Surabaya dan Kabupaten Pasuruan, Kalimantan Selatan teram- bil Kota Banjarmasin dan Kabupaten Banjar, Sulawesi Selatan terpilih Kota Makassar dan Kabupaten Gowa, dan Nusa Tenggara Barat, Kota Mataram dan Kabupaten Lombok Timur. Dengan demikian, wilayah penelitian meliputi 10 Kota dan 10 Kabupaten pada 10 Provinsi sebagaimana terinci pada tabel berikut.

Tabel 2: Lokasi Penelitian

\begin{tabular}{|c|c|c|}
\hline No. & Provinsi & Kota/Kabupaten \\
\hline \multirow{2}{*}{1.} & \multirow{2}{*}{ Sumatera Utara } & Kota Medan \\
\hline & & Kabupaten Langkat \\
\hline \multirow{2}{*}{2.} & \multirow{2}{*}{ Sumatera Barat } & Kota Padang \\
\hline & & Kabupaten Agam \\
\hline \multirow{2}{*}{3.} & \multirow{2}{*}{ Riau } & Kota Pekanbaru \\
\hline & & Kabupaten Kampar \\
\hline \multirow{2}{*}{4.} & \multirow{2}{*}{ Banten } & Kota Serang \\
\hline & & Kabupaten Tangerang \\
\hline \multirow{2}{*}{5.} & \multirow{2}{*}{ Jawa Barat } & Kota Bandung \\
\hline & & Kabupaten Bogor \\
\hline \multirow{2}{*}{6.} & \multirow{2}{*}{ Jawa Tengah } & Kota Semarang \\
\hline & & Kabupaten Klaten \\
\hline \multirow{2}{*}{7.} & \multirow{2}{*}{ Jawa Timur } & Kota Surabaya \\
\hline & & Kabupaten Pasuruan \\
\hline \multirow{2}{*}{8.} & \multirow{2}{*}{$\begin{array}{l}\text { Kalimantan } \\
\text { Selatan }\end{array}$} & Kota Banjarmasin \\
\hline & & Kabupaten Banjar \\
\hline \multirow{2}{*}{9.} & \multirow{2}{*}{$\begin{array}{l}\text { Nusa Tenggara } \\
\text { Barat }\end{array}$} & Kota Mataram \\
\hline & & Kabupaten Lombok Timur \\
\hline \multirow{2}{*}{10.} & \multirow{2}{*}{ Sulawesi Selatan } & Kota Makassar \\
\hline & & Kabupaten Gowa \\
\hline
\end{tabular}

\section{Sampel Penelitian}

Dalam penelitian ini kinerja Pengawas PAI ditinjau menurut penilaian guru Pendidikan Agama Islam (GPAI), terutama untuk menjawab tujuan penelitian yang berkaitan dengan pelaksanaan tugas permbinaan profesi GPAI (supervisi akademik), dan kinerja pengawas PAI dalam pelaksanaan tugas pemantauan penerapan standar nasional PAI (standar isi, standar proses, standar penilaian, dan standar kompetensi lulusan). Kedua penilaian kinerja tersebut akan lebih obyektif penilaiannya dilakukan oleh GPAI. Dalam penelitian ini, GPAI yang menjadi sampel penelitian adalah GPAI dari jenjang SD, GPAI dari jenjang SMP, dan GPAI dari jenjang SMA ataupun SMK. Setiap wilayah Kabupaten ataupun Kota ditentukan masing 30 GPAI (10 GPAI SD, 10 GPAI SMP, dan 10 GPAI SMA/SMK).Jumlah keseluruhan responden GPAI yang direncanakan sebesar 
600 orang.Namun realitasnya setelah pengumpulan data lapangan jumlah responden GPAI keseluruhan sebesar 591 orang.Hal ini dikarenakan terdapat 9 responden yang isian angketnya tidak dapat dilanjutkan dalam pengolahan data.

Sedangkan, untuk menilai kinerja pengawas PAI dalam pelaksanaan tugas penyusunan program pengawasan PAI, pelaksanaan tugas pelaksanaan program pengawasan $\mathrm{PAI}$, dan pelaksanaan tugas evaluasi program pengawasan PAI, menurut tugas yang telah dilakukan oleh pengawas PAI itu sendiri (self assessment). Masing-masing wilayah ditentukan 10 Pengawas PAI, yang terdiri dari Pengawas Tingkat Dasar 5 orang, dan Pengawas Tingkat Menengah 5 orang.Secara keseluruhan jumlah pengawas PAI yang direncanakan dijadikan responden sebesar 200 orang.Hasil pengumpulan data lapangan ternyata terealisasi sebanyak 202 orang.Ada kegairahan pengawas PAI di lapangan untuk perpartisipasi dalam mengisi kuesioner berbentuk self assessment.

\section{Jenis Instrumen dan Sumber Data}

Untuk aspek penilaian kinerja pengawas PAI dalam pelaksanaan tugas pembimbingan profesi guru PAI (supervisi akademik), dengan 10 sub aspeknya dijaring melalui instrumen angket atau berbentuk kuesioner dengan sumber data atau responden guru PAI (SD, SMP, dan SMA/SMK). Sedangkan untuk penilaian aspek dan sub aspek lainnya dijaring dengan menggunakan instrumen pengumpulan data angket yang diisi oleh responden pengawas PAI. Setiap sub aspek diterjemahakan dalam butir-butir item pernyataan ataupun pertanyaan.

\section{Teknis Analisis Data}

Data yang terkumpul yang dijaring melalui kuesioner diolah dan ditabulasi serta dilakukan crosstab antara kinerja pengawas PAI dalam pelaksanaan tugas pembimbingan profesi guru, pelaksanaan pemantauan penerapan standar nasional pendidikan (standar isi, standar proses, standar penilaian, dan standar kompetensi lulusan), pelaksanaan tugas penyusunan program pengawasan, pelaksanaan tugas pelaksanaan program pengawasan, dan pelaksanaan tugas evaluasi program pengawasan, dengan masa kerja pengawas, jabatan sebelum menjadi pengawas, jenis kelamin, tingkat pendidikan, latar belakang pendidikan, dan usia pengawas. Sekor yang diperoleh dari penilaian sebagaimana yang tertuang dalam kuesioner kemudian diberi kategorisasi, yaitu kategori nilaiSangat Kurang dengan rentangan nilai 0 - 54, kategori Kurang berkisar 55 sampai 64, kategori Cukup dengan nilai 65 sampai 79, kategori Baik dari 80 sampai 89, dan kategori Sangat Baik antara 90 sampai 100.

\section{KAJIAN PUSTAKA}

\section{Kinerja}

Kata kinerja jika dilihat dari asal katanya adalah terjemahan dari kata performance, yang menurut The Scribner English Dictionary (1979), berasal dari akar kata "to perform" dengan beberapa entries, yaitu melakukan, menjalankan, melaksanakan, memenuhi atau melaksanakan kewajiban atau tanggung jawab, atau melakukan sesuatu yang diharapkan seseorang atau organisasi.

John Whitmore mengatakan bahwa kinerja adalah suatu perbuatan, suatu prestasi, atau unjuk keterampilan. ${ }^{4}$ Kinerja dalam hal ini ada sesuatu yang dikerjakan dan capaian dari pekerjaan yang dilakukan sebagai sebuah prestasi ataupun sebagai unjuk-kerja.

Menurut Cordosa Games, kinerja merupakan outcome yang dihasilkan dari suatu fungsi pekerjaan atau kegiatan selama waktu tertentu. ${ }^{5} \mathrm{Di}$ sini, kinerja dilihat tidak hanya seseorang melakukan suatu pekerjaan yang ditunjukkan dengan hasil kerja yang dicapai, tapi juga pekerjaan yang dilakukan dalam rangka pelaksanaan fungsi seseorang dalam suatu

${ }^{4}$ John Whitmore, Coaching for Performance, Seni Mengarahkan Untuk Mendongkrak Kinerja, Terjemahan Y. Dwi Helly (Jakarta: Gramedia Pustaka Utama, 1997), h. 170.

${ }^{5} \mathrm{~F}$. Cordosa Games, Manajemen Sumber Daya Manusia (Yogyakarta: Andi Offset 2007), h. 175. 
pekerjaan.Hasil pekerjaan yang dinilai dilihat menurut rentang waktu tertentu, seperti satu tahun.

Tidakjauh berbeda pengertian kinerja dari kedua ahli tersebut, Stolovitch menyebutkan bahwa kinerja merupakan seperangkat hasil yang dicapai dan merujuk pada tindakan pencapaian serta pelaksanaan sesuatu pekerjaan yang ditentukan. ${ }^{6}$ Kinerja dalam konsep tersebut lebih menekankan pada hasil-hasil yang dicapai yang merupakan pelaksanaan dari pekerjaan yang sudah ditentukan.Sejalan dengan itu, Casio menyatakan bahwa kinerja merupakan pencapaian tujuan karyawan atas tugas yang diberikan atau dilaksanakan. Senada dengan pengertian tersebut, tetapi dengan pemahaman yang lebih mendalam, menurut Osborn, kinerja sebagai kuantitas dan kualitas dari pencapaian tugas-tugas yang dilakukan individu. ${ }^{7}$

Berikutnya, hampir sama dengan pengertian kinerja sebagaimana dikemukakan Osborn, Anwar Prabu Mangkunegara berpendapat bahwa kinerja atau prestasi kerja merupakan hasil kerja secara kualitas dan kuantitas yang dicapai oleh seorang pegawai dalam melaksanakan tugasnya sesuai dengan tanggung jawab yang diberikan kepadanya (Anwar Prabu mangkunegara: 2000: 67). Secara lebih tegas lagi, Robert Mathis menyatakan bahwa kinerja pada dasarnya adalah apa yang dilakukan atau tidak dilakukan seorang karyawan.

Sementera itu, Robbins melihat kinerja merupakan hasil evaluasi terhadap pekerjaan yang dilakukan dengan cara membandingkan antara hasil kerja dengan kriteria yang telah ditetapkan bersama. ${ }^{8}$ Dalam hal ini, penilaian kinerja diukur melalui penetapan kriteria-kri-

${ }^{6}$ Harold D. Stolovitch, dan Erica J. Keeps, Handbook of Human Performance Technology: A Comprehensive Guide for Analysis and Solving Perfoemance Problem in Organization, (San Fransisco: Jersey-Bess Publisher, $2^{\text {nd }}$ Edition, 2011), h. 86 .

${ }^{7}$ David Osborne, dan Peter Plastrik, Memangkas Birokrasi: Lima Strategi Menuju Pemerintahan Wirausaha, Terjemahan Abdul Rosjid (Jakarta: PPM, 2000), h. 89.

${ }^{8}$ Stephen P. Robbins, Organized Behaviour: Concept, Controversies, and Aplication (New Jersey: Printese-Hall, 1986), h. 140 teria tertentu yang ditetapkan oleh organisasi ataupun kelompok pekerja seperti kelompok kerja pengawas yang secara bersama-sama menetapkan kriteria penilaian kinerja pengawas.Sterrus dan Aldog melihat kinerja bukanlah pencapaian tujuan sebagaimana criteria yang ditetapkan bersama, tetapi lebih menekankan pada pencapaian tujuan organisasi. ${ }^{9}$ Penekanan kinerja bukan pada bagaimana proses pekerjaan berlangsung, tapi kinerja dinilai baik jika seseorang tersebut mampu menghasilkan pekerjaannya dengan baik sesuai tujuan oragnisasi yang ditetapkan.

Amstrong dan Baron mengutip Bates dan Holton melihat kinerja dari kedua sisi, yaitu sebagai proses dan hasil kerja yang dicapai. ${ }^{10}$ Jadi kinerja tidak cukup menilainya pada hasil akhir yang dicapai seseorang, namun juga melihat pada proses pekerjaan yang dilaluinya.Prawirosentono juga melihat kinerja tidak hanya pada hasil akhir yang dicapai seorang pekerja, tapi juga penilaian kinerjanya didasarkan pada penyempurnaan pekerjaan tersebut sesuai dengan tanggung jawab dan hasil yang diharapkan. ${ }^{11}$

Dengan demikian, yang dimaksudkan kinerja Pengawas Pendidikan Agama Islam dalam tulisan ini adalah hasil kerja yang dicapai seorang pengawas secara keseluruhan baik yang bersifat kuantitatif maupun kualitatif selama periode tertentu dalam melaksanakan tugas kepengawasan berdasarkan ketentuan, sasaran, dan kriteria yang telah ditentukan berkaitan dengan pelaksanaan tugas penyusunan program pengawasan PAI, pelaksanaan tugas pembinaan, pembimbingan, dan pengembangan profesi Guru PAI, pelaksanaan pemantauan penerapan standar nasional PAI, pelaksanaan tugas penilaian hasil pelaksanaan program pengawasan PAI, dan dalam pelaksanaan tugas pelaporan tugas pengawasan PAI

${ }^{9}$ Ramond J. Aldog dan T. Sterrus, Management, (Chicago: South Western Publishing, 1998), h. 77.

${ }^{10}$ Michael Amstrong dan Angela Baron, Performance Management (London: Institute of Personal and Development, 1998), h. 15.

${ }^{11}$ Suryadi Prawirosentono, Kebijakan Kinerja Karyawan (Yogyakarta: BPFF, 1999), h. 2. 


\section{Tugas Pengawas PAI}

Menurut Peraturan Menteri Agama Republik Indonesia Nomor 2 Tahun 2012 Tentang Pengawas Madrasah dan Pengawas Pendidikan Agama Islam pada Sekolah, pada Bab I Ketentuan Umum, pada Pasal 1 ayat (4), menyebutkan bahwa Pengawas Pendidikan Agama Islam yang selanjutnya disebut Pengawas PAI pada sekolah adalah Guru Pegawai Negeri Sipil yang diangkat dalam jabatan fungsional pengawas pendidikan agama Islam yang tugas, tanggung jawab, dan wewenangnya melakukan pengawasan penyelenggaraan Pendidikan Agama Islam pada sekolah.

Pada Pasal 3 ayat (2) disebutkan bahwa Pengawas PAI pada sekolah sebagaimana dimaksud dalam Pasal 2 ayat (1) mempunyai tugas melaksanakan pengawasan Pendidikan Agama Islam pada sekolah.

Selanjutnya, Pengawas PAI pada sekolah mempunyai fungsi melakukan:

a. Penyusunan program Pengawasan PAI;

b. Pembinaan, pembimbingan, dan pengembangan profesi guru PAI;

c. Pemantauan penerapan standar nasional PAI;

d. Penilaian hasil pelaksanaan program pengawasan; dan

e. Pelaporan pelaksanaan tugas kepengawasan.

Berdasarkan fungsi tersebut, Pengawas PAI pada sekolah berwenang untuk melakukan:

a. Memberikan masukan, saran, dan bimbingan dalam penyusunan, pelaksanaan, dan evaluasi pendidikan dan/atau pembelajaran Pendidikan Agama Islam kepada Kepala Sekolah dan instansi yang membidangi urusan pendidikan di Kabupaten/Kota;

b. Memantau dan menilai kinerja guru PAI serta merumuskan saran tindak lanjut yang diperlukan;

c. Melakukan pembinaan terhadap guru PAI; d. Memberikan pertimbangan dalam penilaian pelaksanaan tugas guru PAI kepada pejabat yang berwenang; dan

e. Memberikan pertimbangan dalam penilaian pelaksanaan tugas dan penempatan Guru PAI kepiada Kepala Sekolah dan pejabat yang berwenang.

Memberikan pembinaan adalah memberi arahan, bimbingan, contoh, dan saran kepada sekolah dalam hal ini Guru PAI dalam penyelenggaraan Pendidikan Agama Islam. Memberikan bimbingan adalah upaya Pengawas PAI agar Guru PAI di sekolah yang diawasi mengetahui secara lebih rinci kegiatan yang harus dilaksanakan dan cara melaksanakannya. Tugas memberikan saran adalah upaya Pengawas PAI agar Guru PAI di sekolah yang diawasi dalam melaksanakan tugasnya lebih terarah dan mencapai tujuan yang telah direncanakan. Sedangkan memberikan saran adalah upaya Pengawas PAI agar proses pembelajaran PAI yang dilaksanakan Guru PAI pada sekolah menjadi lebih baik dari hasil yang telah dicapai sebelumnya. Pemberian saran ini juga dapat dilakukan Pengawas PAI kepada Kepala Sekolah dan pejabat instansi yang berwenang agar dapat menindaklanjuti pembinaan yang tidak dapat dilakukan sendiri oleh Pengawas PAI.

Dengan demikian, secara keseluruhan dapat dikatakan bahwa Pengawas PAI pada sekolah bertanggung jawab terhadap peningkatan kualitas perencanaan, proses, dan hasil pendidikan dan/atau pembelajaran PAI pada sekolah mulai dari jenjang TK, SD/SDLB, SMP/SMPLB, SMA/SMALB, dan SMK. Berdasarkan tanggung jawab tersebut, ada lima tugas yang harus dilaksanakan oleh seorang pengawas PAI, yaitu: (1) melaksanakan tugas pembimbingan profesi guru PAI; (2) pemantauan penerapan standar nasional pendidikan yang terdiri dari standar isi, standar proses, standar penilaian, dan standar kompetensi lulusan; (3) pelaksanaan tugas penyusunan program pengawasan; (4) pelaksanaan tugas pelaksanaan program pengawasan; dan (5) pelaksanaan tugas evaluasi pelaksanaan program pengawasan. 
HASIL DAN PEMBAHASAN

\section{Kinerja Pengawas PAI dalam Pembimbingan Profesi Guru PAI}

\section{Kinerja Pengawas PAI per Aspek Bimbingan}

Secara keseluruhan kinerja pengawas PAI dalam pembimbingan profesi guru PAI mendapat nilai 77,48 atau kategori cukup. Dilihat per aspek bimbingan, terdapat 2 aspek yang memperoleh nilai 83,40 dan 80,41 dengan kategori baik. Kedua aspek yang mendapat kategori baik tersebut adalah aspek pembimbingan konsep, prinsip, teori dasar, karakteristik dan kecenderungan mata pelajaran PAI, dan aspek pembimbingan konsep, prinsip, teori dasar, dan perkembangan proses pembelajaran PAI. Apabila dilihat dari jenis pengawas, pengawas tingkat dasar memperoleh nilai yang lebih tinggi dibandingkan pengawas tingkat dasar, walaupun sama-sama masih masuk kategori cukup, yaitu 79,43 dengan 76,32. Dilihat per aspek pembimbingan, dari 10 aspek pembimbingan profesi guru PAI, pengawas tingkat dasar memperoleh kategori baik pada 5 aspek pembimbingan, sedangkan 5 aspek lainnya memperoleh kategori cukup. Pengawas tingkat menengah hanya 1 aspek yang mendapatkan kategoribaik yakni pembimbingan konsep, prinsip, teori dasar, karakteristik dan kecenderungan perkembangan mata pelajaran PAI.

Kinerja bimbingan profesi guru ini sangat penting, karena manfaatnya dirasakan langsung oleh guru dalam meningkatkan mutu pembelajaran. Perolehan kinerja pengawas PAI dalam pembimbingan profesi guru PAI ini tentunya belum maksimal, karena masih dalam kategori cukup. Belum maksimalnya kinerja pengawas PAI, baik pengawas tingkat dasar maupun pengawas tingkat menengah dalam pembimbingan profesi guru PAI dapat disebabkan berbagai hal, seperti beban tugas pengawas PAI yang cukup berat seperti sebagian besar harus membimbing guru PAI lebih dari 50 orang, latar belakang pendidikan pengawas PAI yang kurang mendukung pelaksanaan tugas supervisi edukatif, serta minimnya kesempatan pengawas PAI mengikuti diklat yang berkaitan dengan tugas kepengawasan.

Tabel 3: Kinerja Pengawas PAI dalam Pelaksanaan Tugas Pembimbingan Profesi Guru

\begin{tabular}{|c|c|c|c|c|c|c|c|}
\hline \multirow[t]{2}{*}{ Aspek Supervisi Akademik } & \multicolumn{3}{|c|}{$\begin{array}{l}\text { Nilai Kinerja } \\
\text { Pengawas PAI }\end{array}$} & \multicolumn{2}{|c|}{$\begin{array}{l}\text { Pengawas } \\
\text { Tingkat Dasar } \\
\text { (SD) }\end{array}$} & \multicolumn{2}{|c|}{$\begin{array}{l}\text { Pengawas } \\
\text { Tingkat } \\
\text { Menengah } \\
\text { (SMP_SMA/ } \\
\text { SMK) }\end{array}$} \\
\hline & $\begin{array}{l}\text { Scor } \\
\text { maks. }\end{array}$ & Nilai & Kateg. & Nilai & Kateg. & Nilai & Kateg. \\
\hline $\begin{array}{l}\text { Pembimbingan Konsep, } \\
\text { prinsip, teori dasar, } \\
\text { karakteristik dan kecen- } \\
\text { derungan perkembang- } \\
\text { an mata pelajaran PAI }\end{array}$ & 8 & 83.40 & Baik & 85.28 & Baik & 82.28 & Baik \\
\hline $\begin{array}{l}\text { Pembimbingan konsep, } \\
\text { prinsip, teori dasar dan } \\
\text { perkembangan proses } \\
\text { pembelajaran PAl }\end{array}$ & 8 & 80.41 & Baik & 81.70 & Baik & 79.65 & Cukup \\
\hline $\begin{array}{l}\text { Pembimbingan dalam } \\
\text { menyusun silabus PAI }\end{array}$ & 24 & 79.84 & Cukup & 82.23 & Baik & 78.41 & Cukup \\
\hline $\begin{array}{l}\text { Pembimbingan dalam } \\
\text { memilih dan menggu- } \\
\text { nakan strategis, meto- } \\
\text { de, teknik pembelajaran }\end{array}$ & 36 & 76.57 & Cukup & 77.60 & Cukup & 75.95 & Cukup \\
\hline $\begin{array}{l}\text { Pembimbingan dalam } \\
\text { menyusun RPP PAI }\end{array}$ & 40 & 77.07 & Cukup & 80.02 & Baik & 75.32 & Cukup \\
\hline $\begin{array}{l}\text { Pembimbingan dalam } \\
\text { pelaksanaan pembela- } \\
\text { jaran di kelas/laborato- } \\
\text { rium PAI/tempat ibadah }\end{array}$ & 4 & 73.52 & Cukup & 73.75 & Cukup & 73.38 & Cukup \\
\hline $\begin{array}{l}\text { Pembimbingan dalam } \\
\text { penggunaan media } \\
\text { pendidikan dan fasilitas } \\
\text { pembelajaran }\end{array}$ & 12 & 73.93 & Cukup & 76.59 & Cukup & 72.35 & Cukup \\
\hline $\begin{array}{l}\text { Pembimbingan dalam } \\
\text { memanfaatkan tekno- } \\
\text { logi informasi dalam } \\
\text { pembelajaran }\end{array}$ & 8 & 78.48 & Cukup & 80.35 & Baik & 77.38 & Cukup \\
\hline $\begin{array}{l}\text { Pemotivasian profesi } \\
\text { dan penilaian kinerja } \\
\text { GPAI }\end{array}$ & 52 & 72.29 & Cukup & 73.01 & Cukup & \begin{tabular}{|l}
71.87 \\
\end{tabular} & Cukup \\
\hline $\begin{array}{l}\text { Pembimbingan dalam } \\
\text { pelaksanaan PTK dan } \\
\text { menyusun karya tulis } \\
\text { ilmiah }\end{array}$ & 8 & 72.29 & Cukup & 73.01 & Cukup & \begin{tabular}{|l}
71.87 \\
\end{tabular} & Cukup \\
\hline $\begin{array}{l}\text { Kinerja pembimbingan } \\
\text { profesi guru PAI }\end{array}$ & 200 & 77.48 & Cukup & 79.43 & Cukup & 76.32 & Cukup \\
\hline
\end{tabular}

\section{Kinerja Pengawas PAI Menurut Frekuensi Kunjungan}

Tampaknya frekuensi kunjungan pengawas PAI dalam memberikan pembimbingan profesi guru PAI berpengaruh terhadap perolehan nilai kinerjanya. Pengawas PAI yang hanya satu 
kali melakukan kunjungan pembimbingan profesi guru PAI dalam setahun memperoleh nilai 67,72 dengan kategori cukup. Perolehan nilai tersebut semakin meningkat ketika pengawas melakukan kunjungan lebih dari satu kali dalam setahun. Pengawas yang melakukan kunjungan 2 kali dalam setahun memperoleh nilai 75,90 dengan kategori cukup. Pengawas yang melakukan tiga kali kunjungan dalam setahun kinerjanya mendapat nilai 81,80 dengan kategori baik, begitu seterusnya. Dengan demikian dapat dipahami bahwa semakin banyak frekuensi kunjungan yang dapat dilakukan pengawas PAI dalam setahun semakin banyak manfaat yang dirasakan guru PAI.

\section{Kinerja Pengawas PAI Menurut Lamanya Bimbingan}

Sama seperti jumlah frekuensi kunjungan, lamanya waktu bimbingan juga berpengaruh terhadap kinerja pengawas PAI dalam pembimbingan profesi guru. Pengawas PAI yang lama pembimbingan satu jam pelajaran memperoleh nilai kinerja sebesar 71,71 dengan kategori cukup. Pengawas yang memberikan bimbingan selama 2 jam pelajaran meningkat nilai kinerjanya menjadi 80,54 dan sudah masuk kategori baik. Nilai kinerja tersebut semakin meningkat ketika lama bimbingan yang dilakukan pada tiga jam pelajaran yakni dengan nilai 84,01 dengan kategori baik. Tapi ketika pembimbingan dilakukan lebih dari empat jam pelajaran, terjadi penurunan sedikit dibandingkan nilai kinerja pada lama pembimbingan 3 jam pelajaran, yaitu sebesar 82,14, masih masuk kategori baik. Hal ini mungkin disebabkan waktu yang lama juga menimbulkan kejenuhan dan keletihan pada yang dibimbing maupun yang membimbing.Apa yang dapat disimpulkan sementara yaitu bahwa lamanya pembimbingan sangat berpengaruh terhadap manfaat yang dirasakan guru. Pembimbingan selama 1 jam pelajaran mungkin belum dapat memberikan apa-apa, dibandingkan dengan aspek pembimbingan profesi guru yang begitu banyak dan luas. Pada pembimbingan selama 2 jam pelajaran mulai banyak manfaat yang dirasakan guru. Pembimbingan selama 3 jam pelajaran merupakan pembimbingan yang paling tinggi memberikan manfaat bagi guru PAI.

\section{Kinerja Pengawas PAI Menurut Tempat Bimbingan}

Tempat bimbingan juga mempunyai pengaruh terhadap nilai kinerja pengawas PAI.Tempattempat yang pada umumnya dipakai untuk berlangsungnya pembimbingan profesi guru seperti ruang kelas, ruang guru, ruang kepala sekolah, aula sekolah, dan ruang KKG PAI.Di antara ruang pembimbingan tersebut, ternyata penggunaan kombinasi antara ruang kelas dengan ruang kepala sekolah memberikan nilai kinerja yang paling tinggi yakni sebesar 91,50 atau kategori sangat baik. Sedangkan penggunaan ruang aula sekolah untuk tempat pembimbingan profesi guru memberikan nilai kinerja yang paling rendah, 65,74 atau kategori cukup. Sedangkan pada penggunaan tempat lainnya seperti ruang kelas, ruang guru, ruang kepala sekolah, dan kombinasi penggunaan ruang kelas dan ruang guru, ruang guru dan ruang kepala sekolah, memberikan nilai kinerja di atas 75. Dari data-data ini dapat disimpulkan sementara bahwa pembimbingan kombinasi antara ruang kelas dan ruang kepala sekolah adalah tempat yang paling efektif untuk berlangsungnya pembimbingan profesi guru PAI.Penggunaan ruang kelas sangat memungkinkan pengawas dapat memberikan bimbingan pada saat guru mengajar dan penggunaan ruang kepala sekolah kemungkinan memberikan motivasi tersendiri bagi guru PAI dalam mengikuti pembimbingan dari pengawas. Sedangkan ruang aula sekolah menjadi tempat yang kurang efektif untuk berlangsungnya pembimbingan.

\section{Kinerja Pengawas PAI dan Saat Bimbingan}

Pembimbingan yang dilakukan di luar jam mengajar merupakan saat yang paling efektif, dengan memberikan nilai kinerja sebesar 84,71 atau kategori baik. Sedangkan kombinasi bimbingan saat sedang mengajar di kelas de- 
ngan saat jam istirahat merupakan saat yang kurang efektif, karena hanya memberikan nilai sebesar 68,75 atau kategori cukup. Sedangkan saat bimbingan lainnya seperti pembimbingan diberikan pada saat guru sedang mengajar di kelas, saat jam istirahat, saat di luar jam sekolah, kombinasi saat sedang mengajar di kelas dengan saat jam istirahat dan di luar jam sekolah memberikan nilai kinerja rata-rata di atas 73. Dapat disimpulkan sementara bahwa saat bimbingan yang paling efektif adalah pada saat di luar jam mengajar. Mungkin pada saat di luar jam mengajar, guru merasa tidak terbebani tugas mengajar.

\section{Kinerja Pengawas PAI Menurut Cara Pembimbingan}

Pembimbingan dapat dilakukan secara perseorangan, di mana guru PAI langsung berhadapan dengan pengawas PAI.Cara lainnya adalah bersama dengan guru PAI lainnya, bersama dengan kepala sekolah, kombinasi perseorangan dengan bersama guru PAI lainnya, dan kombinasi perseorangan dengan bersama kepala sekolah. Dari cara pembimbingan tersebut, ternyata cara kombinasi perseorangan dengan bersama kepala sekolah menghasilkan kinerja pengawas PAI yang paling tinggi yakni 85,13 atau kategori baik. Sedangkan cara lainnya memperoleh nilai kinerja sebesar 71 ke atas. Dapat disimpulkan sementara bahwa cara pembimbingan yang paling efektif adalah kombinasi pembimbingan perseorangan dengan bersama kepala sekolah. Efektifnya cara ini mungkin disebabkan selain dapat membangun kemandirian pada pembimbingan perseorangan, juga guru semakin terbangun motivasinya ketika pembimbingan dilakukan dihadapan kepala sekolah, karena guru harus sungguh-sungguh mengikuti pembimbingan.

\section{Kinerja Pengawas PAI Menurut Kabupaten dan Kota}

Kinerja pengawas PAI dalam pelaksanaan tugas pembimbingan profesi guru PAI antara wilayah kota dengan kabupaten dapat dikatakan tidak jauh berbeda. Pengawas PAI pada daerah kota sasaran penelitian memperoleh nilai kinerja sebesar 78,80 atau kategori cukup. Sedangkan, pengawas PAI pada wilayah kabupaten liputan penelitian ini memperoleh nilai rata-rata 76,12 atau kategori cukup.

\section{Kinerja Pengawas PAI Dalam Pemantauan Penerapan Standar Nasional Pendidikan}

Tugas pemantauan penerapan standar nasional pendidikan yang dilakukan pengawas PAI mencakup standar isi, standar proses, standar penilaian, dan standar kompetensi lulusan, secara keseluruhan memperoleh nilai 74,03 atau kategori cukup. Perolehan nilai pada pemantauan penerapan standar kompetensi lulusan memperoleh nilai yang paling tinggi, 76,74 atau kategori cukup. Hal ini mungkin disebabkan pengawas PAI lebih mudah melakukan pemantauan penerapan standar kompetensi lulusan yang dilakukan oleh guru PAI. Sedangkan kinerja pemantauan penerapan standar proses memperoleh nilai kinerja yang paling rendah, 72,13 atau kategori cukup. Hal ini kemungkinan besar dikarenakan pemantauan terhadap penerapan standar proses jauh lebih sulit dilakukan pengawas PAI, karena tidak setiap saat pengawas dapat memantau seluruh proses pembelajaran.

Kinerja pengawas PAI dalam pemantauan penerapan standar nasional pendidikan dilihat dari aspek pengawas tingkat dasar dan pengawas tingkat menengah, tampak bahwa kedua jenis pengawas ini sama-sama mendapat kategori cukup. Tapi secara angka nilai terdapat perbedaan, di mana pengawas tingkat dasar memperoleh nilai 76,73 , sedikit lebih tinggi dari perolehan nilai pada pengawas tingkat menengah yang sebesar 72,43. Malahan pada pemantauan penerapan standar penilaian dan standar kompetensi lulusan, pengawas tingkat dasar memperoleh nilai dengan kategori baik, sedangkan pengawas tingkat menengah tidak satupun memperoleh nilai baik.

Kinerja pengawas PAI dalam pemantauan penerapan standar nasional pendidikan (empat standar), ditinjau dari aspek wilayah kota dan 
Tabel 4: Kinerja Pengawas PAI dalam Pelaksanaan Tugas Pemantauan Penerapan Standar Nasional Pendidikan

\begin{tabular}{|c|c|c|c|c|c|c|c|c|c|}
\hline \multirow[t]{2}{*}{ Provinsi } & \multirow[t]{2}{*}{$\begin{array}{c}\text { Kota/ } \\
\text { Kabupaten }\end{array}$} & \multicolumn{2}{|c|}{ Standar Isi } & \multicolumn{2}{|c|}{ Standar Proses } & \multicolumn{2}{|c|}{$\begin{array}{l}\text { Standar } \\
\text { Penilaian }\end{array}$} & \multicolumn{2}{|c|}{$\begin{array}{c}\text { Standar } \\
\text { Kompetensi } \\
\text { Lulusan }\end{array}$} \\
\hline & & Nilai & Kateg. & Nilai & Kateg. & Nilai & Kateg. & Nilai & Kateg. \\
\hline \multicolumn{2}{|l|}{ Rerata Nilai } & 75.01 & Cukup & 72.13 & Cukup & 75.80 & Cukup & 76.74 & Cukup \\
\hline \multicolumn{2}{|c|}{ Tingkat Dasar (SD) } & 75.87 & Cukup & 74.01 & Cukup & 80.94 & Baik & 81.82 & Baik \\
\hline \multicolumn{2}{|c|}{ Tingkat Menengah (SMP+SMA/SMK) } & 74.49 & Cukup & 71.02 & Cukup & 72.76 & Cukup & 73.72 & Cukup \\
\hline \multirow[t]{2}{*}{ Banten } & Kota Serang & 74.73 & Cukup & 70.38 & Cukup & 78.66 & Cukup & 74.19 & Cukup \\
\hline & Kab. Tangerang & 84.17 & Baik & 81.52 & Baik & 86.41 & Baik & 91.11 & $\begin{array}{c}\text { Sangat } \\
\text { Baik }\end{array}$ \\
\hline \multirow[t]{2}{*}{ Jabar } & Kota Bandung & 89.85 & Baik & 81.15 & Baik & 93.59 & $\begin{array}{c}\text { Sangat } \\
\text { Baik }\end{array}$ & 90.58 & $\begin{array}{c}\text { Sangat } \\
\text { Baik }\end{array}$ \\
\hline & Kab. Bogor & 85.71 & Baik & 84.09 & Baik & 88.74 & Baik & 88.10 & Baik \\
\hline \multirow[t]{2}{*}{$\begin{array}{l}\text { Jawa } \\
\text { Tengah } \\
\end{array}$} & Kab. Klaten & 77.22 & Cukup & 73.64 & Cukup & 80.00 & Baik & 82.22 & Baik \\
\hline & Kota Semarang & 75.00 & Cukup & 76.80 & Cukup & 79.31 & Cukup & 83.91 & Baik \\
\hline \multirow[t]{2}{*}{ Jatim } & Kab. Pasuruan & 88.06 & Baik & 87.58 & Baik & 87.69 & Baik & 90.00 & $\begin{array}{c}\text { Sangat } \\
\text { Baik }\end{array}$ \\
\hline & Kota Surabaya & 72.70 & Cukup & 71.79 & Cukup & 73.47 & Cukup & 74.71 & Cukup \\
\hline \multirow[t]{2}{*}{ Kalsel } & Kab. Banjar & 60.71 & Kurang & 56.01 & Kurang & 59.62 & Kurang & 58.33 & Kurang \\
\hline & Kota Banjarmasin & 70.28 & Cukup & 65.30 & Cukup & 67.69 & Cukup & 70.00 & Cukup \\
\hline \multirow{2}{*}{ NTB } & Kab. Lombok Timur & 62.04 & Kurang & 61.28 & Kurang & 64.10 & Kurang & 69.14 & Cukup \\
\hline & Kota Mataram & 78.33 & Cukup & 78.03 & Cukup & 75.38 & Cukup & 81.11 & Baik \\
\hline \multirow{2}{*}{ Riau } & Kab. Kampar & 74.72 & Cukup & 69.85 & Cukup & 71.03 & Cukup & 73.33 & Cukup \\
\hline & Kota Pekanbaru & 88.33 & Baik & 86.67 & Baik & 86.41 & Baik & 86.67 & Baik \\
\hline \multirow{2}{*}{$\begin{array}{l}\text { Sulawesi } \\
\text { Selatan }\end{array}$} & Kab. Gowa & 80.56 & Baik & 79.09 & Cukup & 90.77 & $\begin{array}{c}\text { Sangat } \\
\text { Baik }\end{array}$ & 95.56 & $\begin{array}{c}\text { Sangat } \\
\text { Baik }\end{array}$ \\
\hline & Kota Makassar & 78.61 & Cukup & 80.91 & Baik & 82.56 & Baik & 88.89 & Baik \\
\hline \multirow{2}{*}{ Sumbar } & Kab. Agam & 60.92 & Kurang & 51.88 & $\begin{array}{l}\text { Sangat } \\
\text { Kurang }\end{array}$ & 55.97 & Kurang & 55.17 & Kurang \\
\hline & Kota Padang & 74.17 & Cukup & 71.82 & Cukup & 70.51 & Cukup & 78.89 & Cukup \\
\hline \multirow{2}{*}{ Sumut } & Kab. Langkat & 57.22 & Kurang & 49.24 & $\begin{array}{l}\text { Sangat } \\
\text { Kurang }\end{array}$ & 48.46 & $\begin{array}{l}\text { Sangat } \\
\text { Kurang }\end{array}$ & 44.44 & $\begin{array}{l}\text { Sangat } \\
\text { Kurang }\end{array}$ \\
\hline & Kota Medan & 64.72 & Kurang & 63.79 & Kurang & 73.59 & Cukup & 56.67 & Kurang \\
\hline
\end{tabular}

kabupaten liputan penelitian menunjukkan bahwa terdapat nilai yang lebih tinggi yang diperoleh pengawas PAI pada kota dibandingkan dengan pengawas PAI pada kabupaten dengan angka 76,25 dan 71,75, walaupun keduanya masih dalam kategori cukup. Hal ini dikarenakan mungkin pengawas PAI di kota lebih mudah mengakses fasilitas pendidikan dibandingkan dengan pengawas PAI di kabupaten. Namun apabila dilihat secara lebih rinci per daerah liputan penelitian, ternyata hal yang seperti itu hanya terjadi pada provinsi Jawa Barat, di mana Kota Bandung nilainya lebih tinggi dari kabupaten Bogor yakni 86,80 dan 85,93, Kalimantan Selatan, di mana Kota Banjarmasin memperoleh nilai 67,40 dan Kabupaten Banjar hanya 58,21 . Hal yang sama juga terjadi pada Provinsi NTB antara Kota Mataram dengan Kabupaten Lombok Timur (77,60 dan 62,67), Provinsi Riau antara Kota Pekanbaru dengan Kabupaten Kampar (87,00 dan 71,53), Provinsi Sumatera Barat antara KotaPadang dengan Kabupaten Agam (72,47 dan 55,31), dan Provinsi Sumatera Utara antara Kota Medan dengan Kabupaten Langkat $(66,13$ dan 50,47). Namun pada daerah liputan penelitian lainnya justru menunjukkan kebalikannya, di mana nilai kinerja pengawas PAI di Kabupaten lebih tinggi dari nilai kinerja yang diperoleh pengawas PAI di daerah Kota, seperti Kabupaten Tangerang 
dengan Kota Serang, Kabupaten Klaten dengan Kota Semarang, Kabupaten Pasuruan dengan Kota Surabaya, dan Kabupaten Gowa dengan Kota Makassar.

Ada yang perlu diperhatikan mengenai perolehan kinerja pengawas dalam pelaksanaan tugas pemantauan penerapan standar nasional pendidikan ini yakni Kabupaten Banjar mendapat kategori kurang, Kabupaten Lombok Timur dengan kategori kurang, Kabupaten Agama dengan kategori kurang, dan Kabupaten Langkat mendapat kategori paling rendah, sangat kurang. Daerah-daerah ini tentunya harus mendapatkan perhatian yang cukup memadai karena penerapan empat standar nasional PAI akan sangat terkait dengan mutu pembelajaran PAI itu sendiri.

\section{Kinerja Pengawas PAI dalam Pelaksanaan Tugas Penyusunan Program Pengawasan}

Secara keseluruhan kinerja pengawas PAI dalam pelaksanaan tugas penyusunan program pengawasan memperoleh nilai 75,09 ata u kategori cukup. Daerah liputan penelitian yang memperoleh nilai tertinggi adalah Kota Pekanbaru, nilai 93,98 atau kategori sangat baik, dan Kabupaten Bogor, 93,13 atau kategori sangat baik. Sedangkan daerah liputan penelitian yang memperoleh nilai rendah dengan kategori sangat kurang ataupun kurang adalah Kabupaten Kampar, Kota Semarang, dan Kabupaten Banjar.

Tabel 5: Kinerja Pengawas PAI dalam Pelaksanaan Tugas Penyusunan Program Pengawasan

\begin{tabular}{|l|l|r|c|}
\hline \multirow{2}{*}{ Provinsi } & \multirow{2}{*}{ Kota/Kabupaten } & \multicolumn{2}{c|}{$\begin{array}{c}\text { Kinerja Penyusunan } \\
\text { Program Pengawasn }\end{array}$} \\
\cline { 3 - 4 } & & \multicolumn{1}{c|}{ Nilai } & \multicolumn{1}{c|}{ Kategori } \\
\hline \multicolumn{2}{|l|}{ Rerata Nilai } & 75.09 & Cukup \\
\hline \multicolumn{2}{|l|}{ Pengawas Tingkat Dasar (PTD) } & 76.88 & Cukup \\
\hline \multicolumn{2}{|l|}{ Pengawas Tingkat Menengah (PTM) } & 72.77 & Cukup \\
\hline Banten & Kota Serang & 67.29 & Cukup \\
\hline & Kab. Tangerang & 74.77 & Cukup \\
\hline Jawa Barat & Kota Bandung & 75.00 & Cukup \\
\hline & Kab. Bogor & 93.13 & Sangat Baik \\
\hline Jawa Tengah & Kota Semarang & 55.00 & Kurang \\
\hline & Kab. Klaten & 81.67 & Baik \\
\hline
\end{tabular}

\begin{tabular}{|l|l|r|c|}
\hline Jawa Timur & Kota Surabaya & 84.58 & Baik \\
\hline & Kab. Pasuruan & 76.25 & Baik \\
\hline Kalimantan Selatan & Kota Banjarmasin & 72.08 & Cukup \\
\hline & Kab. Banjar & 58.75 & Kurang \\
\hline NTB & Kota Mataram & 64.17 & Kurang \\
\hline Riau & Kab. Lombok Timur & 88.54 & Baik \\
\hline & Kota Pekanbaru & 93.98 & Sangat Baik \\
\hline Sulawesi Selatan & Kab. Kampar & 52.86 & Kurang \\
\hline & Kota Makassar & 79.38 & Cukup \\
\hline Sumatera Barat & Kab. Gowa & 86.67 & Baik \\
\hline & Kota Padang & 70.00 & Cukup \\
\hline Sumatera Utara & Kab. Agam & 82.99 & Baik \\
\hline & Kota Medan & 76.60 & Cukup \\
\hline & Kab. Langkat & 66.04 & Cukup \\
\hline
\end{tabular}

\section{Kinerja Penyusunan Program Pengawasan Menurut Jabatan Pengawas}

Jabatan pengawas mempunyai hubungan yang positip terhadap kinerja ini, yaitu semakin tinggi jabatan pengawas, semakin baik nilai kinerjanya. Seperti, nilai yang diperoleh pengawas pertama sebesar 74,60 (cukup), pengawas madya, 74,78 (cukup), dan pengawas utama 87,15 (baik).

\section{Kinerja Penyusunan Program Pengawasan Menurut Jabatan Sebelum Pengawas}

Ada hal yang dapat menjadi renungan, ternyata pengawas yang berasal dari pejabat struktural $(6,44 \%)$ memperoleh nilai yang paling tinggi yakni 81,09 atau kategori baik, sedangkan pengawas PAI yang berasal dari guru PAI maupun kepala madrasah hanya memperoleh nilai sebesar 74,79 dan 74,50 , kategori cukup.

\section{Kinerja Penyusunan Program Pengawasan Menurut Tingkat Pendidikan}

Tingkat pendidikan tampaknya mempunyai hubungan yang positip terhadap kinerja penyusunan program pengawasan, walaupun perbedaannya tidak terlalu jauh. Pengawas PAI yang berpendidikan S-2 memperoleh nilai yang paling tinggi, yaitu 76,83 atau kategori cukup. Pengawas PAI dengan berpendidikan S-1 mem- 
peroleh nilai 73,96 atau kategori cukup, dan pengawas yang berpendidikan D-3 mendapat nilai kinerja 70,83 atau kategori cukup.

\section{Kinerja Penyusunan Program Pengawasan Menurut Latar Belakang Pendidikan}

Ditinjau dari latar belakang pendidikannya ternyata ada hal yang perlu mendapat telaah lebih mendalam, yaitu pengawas PAI yang berasal dari latar belakang fakultas umum justru memperoleh nilai 80,26 atau kategori baik. Sedangkan pengawas yang berlatar belakang pendidikan berasal dari fakultas tarbiyah, fakultas keguruan ilmu pendidikan, yang kurikulumnya sarat dengan muatan kependidikan, memperoleh nilai kinerja di bawah pengawas PAI dari fakultas umum, yaitu nilainya berkisar 75 ke bawah atau nilai cukup. Walaupun perbedaannya tidak terlampau jauh, namun perlu pengkajian yang mendalam terhadap kurikulum dan praktek pendidikan di fakultas tarbiyah yang notabene berkewajiban menyiapkan tenaga calon guru yang berkualitas, tapi pada praktek sehariannya ketika menjadi pengawas kinerjanya masih di bawah pengawas dari fakultas umum.

\section{Kinerja Penyusunan Program Pengawasan Menurut Usia}

Dilihat dari komposisi usianya, hasil-hasil penghitungan menunjukkan bahwa pengawas PAI yang dianggap berada pada usia emas (golden ages) antara 40 sampai 44 tahun, mendapatkan nilai kinerja aspek ini yang paling rendah, 69,12 kategori cukup, dibandingkan pengawas PAI pada usia kelompok lainnya. Misalnya dengan pengawas kelompok usia yang dianggap paling minim pengalaman yakni di bawah 39 tahun, mendapatkan nilai kinerja 75,30 kategori cukup. Dilihat pada kelompok usia lainnya,usia kelompok pengawas PAI yang mencapai nilai kinerja aspek ini yang tertinggi adalah pada usia 45 sampai 49 tahun, 78,77 kategori cukup. Apakah usia kelompok ini merupakan usia puncak pencapaian prestasi?

\section{Kinerja Penyusunan Program Pengawasan Menurut Beban Tugas}

Pada umumnya pegawai dengan beban tugas yang relatif rendah akan mempunyai kinerja yang lebih tinggi dibandingkan dengan pegawai yang memiliki beban tugas berat. Hasil penghitungan terhadap kinerja pengawas dilihat dari beban tugas menunjukkan hal yang sebaliknya. Pengawas PAI dengan beban tugas membimbing lebih dari 50 orang guru PAI memperoleh nilai kinerja yang paling tinggi sebesar 76,76, kategori cukup. Sangat kontras perolehan nilai kinerja ini yang diperoleh pengawas PAI dengan beban tugas membimbing guru PAI 20 orang ataupun di bawahnya dengan nilai hanya 68,29 atau kategori cukup.

\section{Kinerja Pengawas PAI dalam Pelaksanaan Program Pengawasan}

Kinerja pengawas PAI dalam pelaksanaan program pengawasan memperoleh nilai 66,11 atau kategori cukup. Kinerja ini dilihat per daerah cakupan penelitian, terdapat hanya 2 daerah yang memperoleh nilai kategori baik yakni Kabupaten Lombok Timur dan Kabupaten Gowa. Selebihnya memperoleh nilai kategori cukup, kecuali Kota Semarang, Kabupaten Pasuruan, Kabupaten Banjar, Kota Mataram, dan Kabupaten Kampar, masing-masing memperoleh nilai kategori sangat kurang. Ini adalah perbedaan yang cukup mencolok.Rendahnya kinerja ini berdasarkan data tersebut tidak hanya terjadi pada daerah Kabupaten, tapi justru juga terjadi pada daerah Kota.Yang menjadi pertanyaan, tidak terkecuali pada Kabupaten ataupun Kota tersebut, bagaimana pembinaan yang dilakukan Kementerian Agama setempat selama ini terhadap untuk meningkatkan mutu pengawas PAI. 
Tabel 6: Kinerja Pengawas PAI dalam Pelaksanaan Tugas Pelaksanaan Program Pengawasan

\begin{tabular}{|c|c|c|c|}
\hline \multirow{2}{*}{ Provinsi } & \multirow{2}{*}{ Kota/Kabupaten } & \multicolumn{2}{|c|}{$\begin{array}{c}\text { Kinerja Pelaksanaan Program } \\
\text { Pengawasan }\end{array}$} \\
\hline & & Nilai & Kategori \\
\hline \multicolumn{2}{|l|}{ Rerata nilai } & 66.11 & Cukup \\
\hline \multicolumn{2}{|c|}{ Pengawas Tingkat Dasar (PTD) } & 68.13 & Cukup \\
\hline \multicolumn{2}{|c|}{ Pengawas Tingkat Menengah (PTM) } & 63.49 & Kurang \\
\hline \multirow[t]{2}{*}{ Banten } & Kota Serang & 60.83 & Kurang \\
\hline & Kab. Tangerang & 59.26 & Kurang \\
\hline \multirow[t]{2}{*}{ Jawa Barat } & Kota Bandung & 77.92 & Cukup \\
\hline & Kab. Bogor & 78.33 & Cukup \\
\hline \multirow[t]{2}{*}{ Jawa Tengah } & Kota Semarang & 46.25 & Sangat Kurang \\
\hline & Kab. Klaten & 72.92 & Cukup \\
\hline \multirow[t]{2}{*}{ Jawa Timur } & Kota Surabaya & 73.33 & Cukup \\
\hline & Kab. Pasuruan & 52.08 & Sangat Kurang \\
\hline \multirow[t]{2}{*}{ Kalimantan Selatan } & Kota Banjarmasin & 66.25 & Cukup \\
\hline & Kab. Banjar & 51.67 & Kurang \\
\hline \multirow[t]{2}{*}{ NTB } & Kota Mataram & 44.17 & Sangat Kurang \\
\hline & Kab. Lombok Timur & 88.75 & Baik \\
\hline \multirow[t]{2}{*}{ Riau } & Kota Pekanbaru & 79.17 & Cukup \\
\hline & Kab. Kampar & 31.25 & Sangat Kurang \\
\hline \multirow[t]{2}{*}{ Sulawesi Selatan } & Kota Makassar & 77.92 & Cukup \\
\hline & Kab. Gowa & 85.00 & Baik \\
\hline \multirow[t]{2}{*}{ Sumatera Barat } & Kota Padang & 57.50 & Kurang \\
\hline & Kab. Agam & 76.04 & Cukup \\
\hline \multirow[t]{2}{*}{ Sumatera Utara } & Kota Medan & 76.92 & Cukup \\
\hline & Kab. Langkat & 59.17 & Kurang \\
\hline
\end{tabular}

\section{Kinerja Pelaksanaan Program Pengawasan Menurut Jabatan Pengawas}

Sebagaimana pada aspek kinerja sebelumnya, jabatan pengawas amat berpengaruh terhadap kinerja pelaksanaan program pengawasan. Pengawas PAI dengan jabatan pengawas utama memperoleh nilai yang paling tinggi sebesar 87,15 atau kategori baik. Sedangkan pengawas PAI dengan jabatan di bawahnya memperoleh nilai rata-rata sekitar 74 atau kategori cukup. Dalam hal ini dapat dikatakan bahwa pengawas utama lebih berpengalaman dan lebih terampil dalam melaksanakan tugas pelaksanaan program pengawasan.

\section{Kinerja Pelaksanaan Program Pengawasan Menurut Masa Kerja Pengawas}

Pengawas PAI yang telah mempunyai masa kerja 10 sampai 14 tahun memiliki kinerja yang paling tinggi dibandingkan dengan pengawas PAI pada kelompok masa kerja lainnya, yaitu 72,22 atau kategori cukup. Sedangkan pengawas PAI yang mempunyai kinerja aspek ini yang terendah adalah pada kelompok masa kerja lebih dari 15 tahun.Angka ini juga menunjukkan suatu anomaly karena bertentangan kelaziman, yang sepatutnya pengawas PAI kelompok berpengalaman ini memiliki kinerja yang lebih tinggi.Hal ini terbukti pada kelompok masa kerja mulai 4 tahun ke bawah, 5 sampai 9 tahun, dan kelompok masa kerja 10 sampai 14 tahun menunjukkan trend nilai kinerja yang senantiasa meningkat. Anomali ini mungkin disebabkan beberapa faktor yang mempengaruhinya, antara lain adanya faktor kejenuhan dalam melakukan tugas yang sama setiap hari sebagai pengawas PAI, dan faktor lainnya.

\section{Kinerja Pelaksanaan Program Pengawasan Menurut Jabatan Sebelumnya}

Pengawas PAI yang berasal dari jabatan struktural memperoleh nilai yang paling tinggi yakni sebesar 78,85 atau kategori cukup. Pengawas yang berasal dari kepala madrasah memperoleh nilai 66,08 atau kategori cukup. Tetapi pengawas yang berasal dari guru PAI memperoleh nilai paling rendah, 64,02 atau kategori kurang. Kesimpulan sementara yang dapat dikemukakan adalah pengawas yang berasal dari struktural dan kepala madrasah adalah pengawas PAI yang sarat dengan pengalaman dan penuh percaya diri, diabndingkan dengan pengawas yang berasal dari guru PAI.

\section{Kinerja Pelaksanaan Program Pengawasan Menurut Tingkat Pendidikan}

Tampaknya tingkat pendidikan kurang berpengaruh terhadap kinerja pada aspek ini. Hampir semua tingkat pendidikan menun- 
jukkan nilai yang belum menggembirakan, yaitu memperoleh nilai dengan kategori cukup (rata-rata 64 ke atas).

\section{Kinerja Pelaksanaan Program Pengawasan Menurut Latar Belakang Pendidikan}

Pengawas PAI yang berasal dari fakultas tarbiyah memperoleh nilai yang paling tinggi dibandingkan dengan pengawas PAI dari latar belakang pendidikan FKIP, fakultas agama, maupun dari fakultas umum, yaitu 70,50 atau kategori cukup.Perolehan kategori cukup ini sebenarnya kurang mendukung pengawas dalam tugas utama sebagai pengendalian mutu pembelajaran PAI.

\section{Kinerja Pelaksanaan Program Pengawasan Menurut Usia}

Sebagaimana temuan sebelumnya, kinerja pelaksanaan program pengawasan pada kelompok usia 40 sampai 44 tahun merupakan nilai yang terendah dibandingkan dengan kelompok umur lainnya. Kelompok usia ini hanya mendapat nilai sebesar 59,07 atau kategori kurang. Hal ini bertentangan lagi dengan adagium yang menyatakan bahwa karir pekerja dimulai pada usia 40 tahun.

\section{Kinerja Evaluasi Pelaksanaan Program Pengawasan}

Kinerja pengawas PAI dalam melaksanakan tugas evaluasi ini memperoleh nilai 64,70 atau kategori kurang. Ketiga kinerja ini (kinerja penyusunan program pengawasan, kinerja pelaksanaan program pengawasan, dan kinerja evaluasi pelaksanaan program pengawasan) menunjukan trend penuruan nilai kinerja. Kinerja penyusunan program nilainya 75,09, kinerja pelaksanaan program nilainya semakin menurun menjadi 66,11, dan kinerja evaluasi pelaksanaan program menurun lagi nilainya. Apakah kecenderungan ini merupakan indikasi pengawas PAI kurang dapat mengoperasionalkan secara baik rencana program pengawasan ke dalam tindakan di lapangan, serta mengalami kesulitan dalam mengeva- luasi apa-apa yang telah dilaksanakan sebagai pertanggungjawaban tehadap kegiatan yang telah dilaksanakan. Bisa jadi apa yang direncanakan tidak sesuai dengan apa yang dipraktekkan di lapangan, sehingga dengan demikian akan mengalami kesulitan pada tataran membuat laporan evaluasinya. Dilihat per daerah liputan penelitian ini, terdapat 5 daerah yang memperoleh nilai sangat kurang, yaitu Kota Semarang, Kabupaten Banjar, Kota Mataram, Kabupaten Kampar, dan Kota Padang.

Tabel 7: Kinerja Pengawas PAI dalam

\section{Pelaksanaan Tugas Evaluasi Pelaksanaan} Program Pengawasan

\begin{tabular}{|c|c|c|c|}
\hline \multirow{2}{*}{ Provinsi } & \multirow{2}{*}{ Kota/Kabupaten } & \multicolumn{2}{|c|}{$\begin{array}{l}\text { Kinerja Evaluasi Pelaksanaan } \\
\text { Program Pengawasan }\end{array}$} \\
\hline & & Nilai & Kategori \\
\hline \multicolumn{2}{|l|}{ Rerata Nilai } & 64.70 & Kurang \\
\hline \multicolumn{2}{|c|}{ Pengawas Tingkat Dasar (PTD) } & 65.13 & Cukup \\
\hline \multicolumn{2}{|c|}{ Pengawas Tingkat Menengah (PTM) } & 64.13 & Cukup \\
\hline \multirow{2}{*}{ Banten } & Kota Serang & 58.75 & Kurang \\
\hline & Kab. Tangerang & 52.78 & Sangat Kurang \\
\hline \multirow{2}{*}{ Jawa Barat } & Kota Bandung & 71.88 & Cukup \\
\hline & Kab. Bogor & 70.00 & Cukup \\
\hline \multirow{2}{*}{ Jawa Tengah } & Kota Semarang & 44.38 & Sangat Kurang \\
\hline & Kab. Klaten & 74.38 & Cukup \\
\hline \multirow{2}{*}{ Jawa Timur } & Kota Surabaya & 78.13 & Cukup \\
\hline & Kab. Pasuruan & 59.38 & Kurang \\
\hline \multirow{2}{*}{$\begin{array}{l}\text { Kalimantan } \\
\text { Selatan }\end{array}$} & Kota Banjarmasin & 72.50 & Cukup \\
\hline & Kab. Banjar & 43.75 & Sangat Kurang \\
\hline \multirow{2}{*}{ NTB } & Kota Mataram & 42.50 & Sangat Kurang \\
\hline & Kab. Lombok Timur & 80.63 & Baik \\
\hline \multirow{2}{*}{ Riau } & Kota Pekanbaru & 88.19 & Baik \\
\hline & Kab. Kampar & 32.03 & Sangat Kurang \\
\hline \multirow{2}{*}{ Sulawesi Selatan } & Kota Makassar & 71.25 & Cukup \\
\hline & Kab. Gowa & 84.38 & Baik \\
\hline \multirow{2}{*}{ Sumatera Barat } & Kota Padang & 46.25 & Sangat Kurang \\
\hline & Kab. Agam & 78.65 & Cukup \\
\hline \multirow{2}{*}{ Sumatera Utara } & Kota Medan & 76.92 & Cukup \\
\hline & Kab. Langkat & 59.38 & Kurang \\
\hline
\end{tabular}

\section{Kinerja Evaluasi Pelaksanaan Program Menurut Jabatan Pengawas}

Sama seperti kinerja sebelumnya, pengawas PAI dengan jabatan pengawas utama memperoleh nilai tertinggi, 91,67 atau kategori sangat baik.Nilai kinerja pengawas PAI jenjang peng- 
awas utama cukup jauh kesenjangannya dengan nilai kinerja pada pengawas pada jabatan pengawas muda dan madya. Pengawas madya malahan perolehan nilai kinerjanya berada di bawah pengawas muda.

\section{Kinerja Evaluasi Pelaksanaan Program Menurut Masa Kerja}

Lagi-lagi hal yang sama terjadi pada aspek ini. Seharusnya pengawas PAI dengan masa kerja terlama memiliki kinerja yang lebih tinggi, tapi sebaliknya justru yang paling rendah. Peningkatan kinerja pengawas PAI pada kelompok usia di bawah 4 tahun, kelompok usia 5 sampai 9 tahun, dan kelompok usia 10 sampai 14 tahun terlihat adanya trend peningkatan. Kemungkinan besar pengawas pada kelompok di atas 15 tahun adalah pengawas-pengawas yang hampir memasuki usia pensiun, sehingga seiring dengan usia dan semakin menurunnya motivasi dan kekuatan fisik dan daya pikir menyebabkan kinerja yang dapat ditampilkan tidak maksimal.

\section{Kinerja Evaluasi Pelaksanaan Program Me nurut Jabatan Sebelumnya}

Pengawas PAI yang berasal dari jabatan struktural mempunyai nilai kinerja yang lebih tinggi dibandingkan dengan pengawas PAI yang berasal dari guru PAI maupun kepala madrasah, yaitu sebesar 76,44 atau kategori cukup. Sedangkan pengawas dari jabatan guru PAI dan kepala madrasah hanya mendapat nilai kinerja dengan kategori kurang.Apakah kenyataan ini perlu memikirkan kembali peraturan rekrutmen yang menutup peluang pejabat struktural untuk menjabat fungsional pengawas.

\section{Kinerja Evaluasi Pelaksanaan Program Menurut Tingkat Pendidikan}

Kinerja evaluasi pengawas dilihat dari tingkat pendidikannya menunjukkan hal yang memprihatinkan. Pengawas PAI dengan jenjang pendidikan S-2 hanya dapat menggapai nilai 65,36 atau kategori cukup. Mengapa tingkat pendidikan yang tinggi ini kurang berkorela- si positip dengan pencapaian kinerja.Telaah mendalam kiranya sangat diperlukan untuk melihat akar permasalahannya.

\section{Kinerja Evaluasi Pelaksanaan Program Menurut Latar Belakang Pendidikan}

Pada aspek kinerja ini pengawas PAI dengan latar belakang fakultas tarbiyah mencapai nilai kinerja tertinggi, 70,25 atau kategori cukup. Sedangkan pengawas dengan latar belakang FKIP, fakultas agama, dan fakultas umum hanya memperoleh nilai dengan kategori kurang.

\section{Kinerja Evaluasi Pelaksanaan Program Menurut Usia}

Kinerja evaluasi yang dilihat dari usianya memperlihatkan adanya ketidak-konsistenan, yaitu pengawas pada kelompok usia sama atau di bawah 39 tahun memiliki kinerja yang paling tinggi, yaitu memperoleh nilai 71,43 atau kategori cukup, tapi pada kelompok usia 40 sampai 44 tahun justru menurun menjadi 53,31 atau kategori kurang. Sedangkan pada kelompok usia lainnya mencapai sekitar 66 ke atas atau kategori cukup. Di duga kelompok usia 39 tahun atau ke bawah merupakan pengawas hasil rekrutmen langsung sebagai pengawas, sehingga sudah memiliki basis pengetahuan kepengawasan yang cukup.

\section{PENUTUP}

\section{Kesimpulan}

1. Kinerja Pengawas PAI pada sekolah dalam pelaksanaan pembimbingan profesi guru PAI (supervisi akademik atau edukatif):

a. Kinerja Pengawas PAI pada sekolah dalam pelaksanaan pembimbingan profesi guru PAI (supervisi akademik atau edukatif), memperoleh nilai pada taraf cukup. Dengan kinerja yang dicapai pada taraf cukup ini pada hakekatnya pengawas PAI belum dapat secara maksimal memberikan pembimbingan profesi guru PAI. Sebab fungsi pengawas PAI adalah melakukan pengendalian mutu 
pembelajaran PAI. Berarti, pengendalian mutu yang dilakukan masih taraf sedang-sedang saja, seharusnya agar dapat meningkatkan mutu pembelajaran PAI, kinerja pengawas PAI pada aspek ini masuk pada taraf baik ataupun sangat baik. Kinerja pembimbingan profesi guru ini sangat penting karena manfaatnya sangat dirasakan langsung oleh guru PAI dalam meningkatkan mutu pembelajaran.

b. Pengawas PAI yang melakukan kunjungan pembimbingan yang lebih intens atau sering dalam setahun memiliki kinerja yang lebih tinggi ketimbang pengawas PAI yang melakukan kunjungan pembimbingan profesi guru PAI yang hanya sekali dalam setahun.

c. Pengawas PAI yang melakukan pembimbingan profesi guru PAI selama 3 jam pelajaran setiap kunjungan memiliki kinerja yang paling tinggi dengan kategori baik.

d. Pengawas PAI yang melakukan pembimbingan profesi guru PAI kombinasi di ruang kelas dan ruang kepala sekolah memiliki kinerja pada kategori sangat baik.

e. Pengawas PAI yang melakukan pembimbingan profesi guru PAI di luar jam mengajar memiliki kinerja yang paling tinggi pada kategori baik.

f. Pengawas PAI yang melakukan pembimbingan profesi guru PAI kombinasi secara perseorangan dan bersama dengan kepala sekolah memiliki kinerja yang paling tinggi dengan kategori baik.

g. Tidak ada perbedaan yang signifikan kinerja pengawas PAI di Kota dan Kabupaten daerah liputan penelitian ini dalam pembimbingan profesi guru PAI.

2. Kinerja Pengawas PAI dalam Pemantauan Penerapan Standar Nasional Pendidikan:

a. Kinerja pengawas PAI dalam pelaksanaan tugas pemantauan penerapan standar nasional pendidikan (standar isi, standar proses, standar penilaian, dan standar kompetensi lulusan) memiliki nilai dengan kategori cukup.

b. Kinerja pengawas PAI dalam pemantauan penerapan standar proses memiliki kinerja yang paling rendah dibandingkan dengan kinerja pemantauan pada ketiga standar lainnya.

c. Kinerja pengawas PAI dalam pelaksanaan pemantauan penerapan standar nasional pendidikan pada daerah Kabupaten Banjar, Kabupaten Lombok Timur, Kabupaten Agam, Kabupaten Langkat mendapat nilai dengan kategori kurang.

3. Kinerja Pengawas PAI dalam pelaksanaan tugas penyusunan program pengawasan:

a. Kinerja pengawas PAI dalam pelaksanaan tugas penyusunan program pengawasan memperoleh nilai dengan kategori cukup.

b. Kinerja pengawas PAI yang berasal dari jabatan struktural (Kasi Mapendais) memiliki kinerja yang lebih tinggi (kategori baik) dibandingkan dengan yang berasal dari guru PAI maupun kepala madrasah (kategori cukup).

c. Pengawas PAI pada kelompok usia 40 sampai 44 tahun memiliki kinerja yang paling rendah dibandingkan kelompok usia lainnya.

4. Kinerja Pengawas PAI dalam pelaksanaan program pengawasan:

a. Kinerja pengawas PAI dalam pelaksanaan program pengawasan berada pada kategori cukup.

b. Pengawas PAI yang berasal dari jabatan struktural memiliki nilai kinerja yang paling tinggi. Sedangkan, pengawas PAI yang berasal dari guru PAI memiliki nilai kinerja yang paling rendah dengan kategori kurang.

c. Pengawas PAI pada kelompok usia 40 sampai 44 tahun memiliki nilai kinerja 
yang paling rendah dibandingkan pengawas PAI pada kelompok usia lainnya.

5. Kinerja pengawas PAI dalam pelaksanaan evaluasi pelaksanaan program pengawasan:

a. Kinerja pengawas PAI dalam pelaksanaan evaluasi pelaksanaan program pengawasan mendapatkan nilai dengan kategori kurang.

b. Pengawas PAI yang berasal dari pejabat struktural memiliki kinerja yang lebih tinggi dibandingkan dengan yang berasal dari guru PAI dan kepala madrasah.

c. Pengawas PAI pada usia 40 sampai 44 tahun memiliki nilai kinerja yang paling rendah dengan kategori kurang dibandingkan dengan kelompok usia lainnya.

\section{Rekomendasi}

1. Perlu peningkatan kemampuan pengawas PAI melalui: (1) pemberian kesempatan mengikuti diklat yang diselenggarakan oleh Pusdiklat Tenaga Teknis Pendidikan dan Keagamaan ataupun Balai Diklat Keagamaan dengan menekankan muatan materi kurikulum yang mendukung pelaksanaan tugas pembimbingan profesi guru PAI, pelaksanaan tugas penyusunan program pengawasan, pelaksanaan tugas pelaksanaan program pengawasan, dan dalam pelaksanaan tugas evaluasi pelaksanaan program pengawasan, dan (2) Direktorat pendidikan Agama Islam perlu mendorong dengan memberikan dukungan dana dalam bentuk block grant untuk kegiatan akademik pokjawas PAI dalam rangka meningkatkan profesionalitas pengawas PAI

2. Cakupan aspek pembimbingan profesi guru (supervisi akademik) begitu luas, sehingga pengawas mengalami kesulitan melaksanakannya secara keseluruhan dengan efektif. Untuk jangka panjang ke depan, Direktorat Pendidikan Agama Islam maupun Direktorat Pendidikan Madrasah perlu melakukan spesialisasi bidang keahlian pengawas, sehingga tugas pembimbingan profesi guru (supervisi akademik) tidak lagi sifatnya perorangan, tetapi sudah dalam bentuk kerja tim.

3. Direktorat Pendidikan Madrasah dan Direktorat Pendidikan Agama Islam perlu mengembangkan sistem pembimbingan profesi guru (supervisi akademik) jarak jauh secara online untuk mengatasi hambatan waktu dan besarnya beban tugas pengawas.

4. Untuk memperoleh tenaga pengawas yang profesional, perlu dilakukan uji kompetensi dalam rekrutmen tenaga pengawasyang mencakup kompetensi supervisi akademik, kompetensi evaluasi pendidikan, kompetensi kepribadian, dan kompetensi penelitian dan pengembangan.

\section{SUMBER BACAAN}

Aldog, Ramond J., dan Sterrus, Timothy (1998): Management, Chicago, South Western Publishing.

Amstrong, Michael, dan Baron, Angela (1998): Perfoemance Management. London, Institute of Personal and Development.

Bondi, dan J. Wiles (2007): Supervision a Guide to Practice. Second Edition, London, Charles E. Merril Publishing Company

Direktorat Jenderal Pendidikan Islam (2010): Statistik Pendidikan Islam Tahun 2010. Jakarta, Direktorat Jenderal Pendidikan Islam Kementerian Agama R.I.

Games, F. Cordosa (2007): Manajemen Sumber Daya Manusia. Yogyakarta, Andi Offset

Hasibuan, SP., Melayu (1997): Manajemen Sumber Daya Manusia: Dasar dan Kunci Keberhasilan. Jakarta, PT. Toko Gunung Agung

Keputusan Bersama Menteri Pendidikan Nasional R.I. Nomor 03420/O/1996 dan Kepala Badan Administrasi Kepegawaian Negara R.I. Nomor 38 Tahun 1996 tentang Petunjuk Teknis Pelaksanaan Jabatan Fungsional Pengawas Sekolah dan Angka Kreditnya 
Keputusan Menteri Pendayagunaan Aparatur Negara Nomor 118/1996 tentang Jabatan Fungsional Pengawas dan Angka Kreditnya: Jakarta: Dirjen Dikdasmen

Osborne, David, dan Plastrik, Peter (2000): Memangkas Birokrasi: Lima Strategi Menuju Pemerintahan Wirausaha. Terjemahan Abdul Rosjid. Jakarta, PPM

Peraturan Menteri Agama R.I. Nomor 2 Tahun 2012 tentang Pengawas Madrasah dan Pengawas Pendidikan Agama Islam pada Sekolah. Kementerian Agama R.I. Jakarta: Kementerian Agama R.I.

Peraturan Pemerintah Republik Indonesia, Nomor 12 Tahun 2007 tentang Standar Pengawas Sekolah/Madrasah

Peraturan Pemerintah Republik Indonesia, Nomor 19 Tahun 2005 tentang Standar Nasional Pendidikan. Jakarta: Departemen Pendidikan Nasional Republik Indonesia

Peraturan Pemerintah Republik Indonesia, Nomor 19 Tahun 2005 tentang Penetapan Angka Kredit Jabatan Fungsional Pengawas Sekolah. Semarang: Duta Nusindo

Prawirosentono, Suryadi (1999): Kebijakan Kinerja Karyawan. Yogyakarta, BPFF

Puslitbang Pendidikan Agama dan Keagamaan (2005): Kinerja Pokjawas Pendidikan Agama Islam pada Sekolah. Jakarta, Badan Litbang dan Diklat Kementerian Agama R.I.
Robbins, Stephen P. (1986): Organized Behaviour: Concept, Controversies and Aplication. New Jersey, Printese-Hall

Sahertian, Piet, A. (2000): Konsep Dasar dan Teknik Supervisi Pendidikan Dalam Rangka Pengembangan Sumber Daya Manusia, Jakarta, Rineka Cipta

Saud, Udin, Syaefudin (2009): Pengembangan Profesi Guru. Bandung, PT Alfabeta

Singarimbun, Masri, dan Effendi Sofian (2000): Metode Penelitian Survei, Jakarta, LP3ES

Stolovitch, Harold D., J. Keeps, Erica (2011): Handbook of Human Performance Technology: A Comprehensive Guide for Analysis and Solving Performance Problem in Organization, San Fransisco, Jersey-Bess Publisher, $2^{\text {nd }}$ Edition

Suhardan, Dadang, dkk. (2003): Supervisi Rencana Program Pembelajaran. Ciputat Tangerang, Rian Putra

Undang-undang Republik Indonesia, Nomor 20 Tahun 2003 tentang Sistem Pendidikan Nasional. Jakarta: PT Putra Timur

Uno, B., Hamzah (2011): Profesi Kependidikan: Problema, Solusi, dan Reformasi Pendidikan Indonesia. Jakarta, Bumi Aksara

Whitmore, John, Coaching for Performance (1997): Seni Mengarahkan untuk Mendongkrak Kinerja. Terjemahan Helly, Y., Dwi. Jakarta, Gramedia Pustaka Utama 